\title{
PENGEMBANGAN BUKU BAHASA MADURA SEBAGAI PENUNJANG PEMBELAJARAN MUATAN LOKAL DI SEKOLAH DASAR
}

\author{
Riska Fita Lestari ${ }^{1}$, Lutfi Irawan Rahmat ${ }^{2}$ \\ 1,2 Universitas PGRI Banyuwangi \\ 1riskafl28@gmail.com, 2lutfiirawan04@gmail.com
}

\begin{abstract}
The development of language science has an important role in using books as a medium of learning. Madura language is a local content subject that is introduced to students in elementary schools. The development of language science has an important role in using books as a medium of learning. Based on that background, the problem formulation in this study is how pepak development. This research uses Research and Development $(R \& D)$ approach. The subjects of the study were teachers and a Team of Experts consisting of Expert Lecturers and Madurese Culturalists. The data collection techniques in this study use observations, library studies, documentation, interviews, and questionnaires for prototype assessment. Data analysis techniques use qualitative descriptive. The result of this study is a product in the form of a prototype book in Madura language that will make it easier for elementary school students to learn it.
\end{abstract}

Keywords: local content, madura language, elementary school

\begin{abstract}
ABSTRAK
Pengembangan ilmu pengetahuan bahasa memiliki peranan penting dalam menggunakan buku sebagai media pembelajaran. Bahasa Madura merupakan mata pelajaran muatan lokal yang dikenalkan kepada peserta didik di sekolah dasar. Pengembangan ilmu pengetahuan bahasa memiliki peranan penting dalam menggunakan buku sebagai media pembelajaran. Berdasarkan latar belakang tersebut, rumusan masalah dalam penelitian ini adalah bagaimanakah pengembangan pepak. Penelitian ini menggunakan pendekatan Research and Development (R\&D). Subjek penelitian adalah guru dan Tim Ahli yang terdiri dari Dosen Ahli dan Budayawan Madura. Teknik pengumpulan data dalam penelitian ini menggunakan observasi, studi pustaka, dokumentasi, wawancara, dan angket untuk penilaian prototipe. Teknik analisis data menggunakan deskriptif kualitatif. Hasil dari penelitian ini sebuah produk yang berupa prototipe buku berbahasa Madura sebagai penunjang pembelajaran muatan lokal di sekolah dasar yang akan mempermudah siswa dalam mempelajarinya.
\end{abstract}

Kata Kunci: muatan lokal, bahasa madura, sekolah dasar 


\section{A. Pendahuluan}

Bahasa Madura merupakan mata pelajaran muatan lokal yang dikenalkan kepada peserta didik pada semua jenjang sekolah. Di Indonesia bahasa Madura dinyatakan berkedudukan sebagai bahasa daerah. berdasarkan Undang-undang Dasar 1945 Bab XV Pasal 36 Bahasa daerah (Undang-Undang Dasar Negara Republik Indonesia 1945, n.d.) adalah salah satu unsur kebudayaan nasional dan dilindungi oleh negara. Indikator masalah ini merupakan tantangan terhadap suku Madura yang berada mulai mengabaikan budaya kearifan lokal Madura. Oleh karena itu, Sebagian peserta didik hanya mengenal bahasa Madura, sedangkan carakan Madura dan tinggkatan bahasa yang lebih halus kurang dipahami peserta didik

Dalam dunia pendidikan, (Wicaksono Alam \& Fikri Bariska, 2018) buku penunjang yang dikhususkan untuk bahasa Madura terbatas jumlahnya. Guru dan peserta didik terkadang hanya menggunakan buku teks dan internet. Mata pelajaran bahasa Madura dianggap sebagai materi yang di anggap sulit dan masyarakat mulai mengangap tidak penting maka seharusnya ada buku yang menyajikan materi bahasa Madura, sehingga peserta didik akan lebih mengenal dan fokus dalam mempelajarinya.

Penelitian ini akan memproses pengembangkan mata pelajaran muatan local bahasa Madura dalam bentuk prototipe yang diharapkan hal ini dapat membantu proses pembelajaran dan meningkatkan keterampilan membaca dan menulis bahasa.

Berdasarkan data identifikasi permasalahan, sehingga peneliti ini Pengembangan buku bahasa Madura ini bisa menambah referensi untuk pembelajaran bahasa Madura dan dapat memelihara kebudayaan bahasa Madura serta menjadi bahan referensi sebagai penunjang pembelajaran muatan lokal..

Sebelum adanya penelitian ini ada beberapa Penelitian yang relevan dengan penelitian yaitu: Penelitian pertama (Fifana, 2012). Tidak ada kesamaan pada bagian objek atau kajian penelitian. Hanya saja, hipotesis penelitian yang ditemukan oleh bisa dijadikan sebagai aspek referensi untuk mengembangkan sebuah buku. 
Kedua oleh (Lestari, 2011) mengembangkan sebuah buku bahan ajar pembelajaran bahasa Indonesia yang disesuaikan dengan kurikulum pembelajaran bahasa Indonesia dengan objek siswa Sekolah Dasar pada pokok bahasan memahami cerita. Penelitian ini memiliki kesamaan yaitu pada jenis penelitian, objek penelitian, dan salah satu kajian penelitiannya.

Ketiga oleh (Ardiyani, 2013) memiliki persamaan dengan penelitian ini terletak pada subjek penelitian dan tujuan penelitiannya. Perbedaan antara penelitian ini dan peneltian Ardiyani terletak pada jenis penelitian. Penelitian ini merupakan proses penelitian pengembangan, sedangkan penelitian yang dilakukan oleh Ardiyani adalah Penelitian Tindakan Kelas.

\section{Bahan Ajar}

Menurut (Prastowo, 2011) bahan ajar adalah buku yang berisi ilmu pengetahuan, yang diturunkan dari kopetensi dasar yang tertuang dalam kurikulum, dimana buku tersebut digunakan oleh peserta didik untuk belajar. Sedangkan menurut (Sitepu, 2012) juga menjelaskan pengertian bahan ajar di mana bahan ajar terdiri atas segala media.

Menurut (Nunung Nurjanah, 2018) Dapat disimpulkan bahwa Bahan pembelajaran harus dirancang berdasarkan kebutuhan siswa, dan dalam merancang bahan ajar guru harus kreatif dalam mengembangkan bahan ajar berdasarkan kurikulum dan kebutuhan siswa.

2. Bahasa dan Carakan Madura Sebagai muatan lokal Menurut (Halim, 1976). Sebagai bahasa daerah yang besar, bahasa ini perlu dipertahankan, dibina dan dikembangkan terutama dalam hal perannya sebagai sarana pengembangan untuk kelestarian kebudayaan daerah sebagai pendukung kebudayaan nasional. Sesuai dengan Keputusan Gubernur Jawa Timur yang ditindaklanjuti oleh Pemerintah Kabupaten/Kota tentang Penetapan Muatan Lokal Wajib Bahasa Daerah (bahasa Madura) bagi daerah pengguna bahasa Madura.

Dapat diartikan bahwa dengan keputusan peraturan pemerintah dan sesuai dengan peran Bahasa daerah Menggunakan Carakan Madura merupakan sering dipakai oleh 
Pendas : Jurnal IImiah Pendidikan Dasar, ISSN Cetak : 2477-2143 ISSN Online : 2548-6950 Volume VI Nomor 01, Juni 2021

masyarakat madura pada zaman madura kuno. Carakan Madura memang berasal dari huruf Madura kuno yang di adopsi menjadi (a na ca ra ka da ta sa wa la pa dha ja ye nya ma ga be ta nga). Seiring dengan perkembangan zaman madura kuno, maka huruf carakan ini merupakan salah satu alat yang digunakan untuk berkomunikasi. Identitas dan eksistensi Carakan Madura merupkan kebudayaan madura yang harus dipertahankan sampai saat ini.

2. Pembelajaran Bahasa Madura SD

Menurut (Dimyati; Mudjiono, 2002) menerangkan bahwa terciptanya pembelajaran terdiri dari dua peran antara siswa dan guru. Peran sebagai siswa adalah melalui tahapan proses belajar, untuk tercapainya hasil dari belajar, serta menggunakan hasil dari belajar. Peran sebagai guru adalah untuk membuat rencana instruksional, untuk menciptakan kegiatan belajar mengajar yang kondusif, bertindak sebagai mengajar untuk membing siswa, serta berperan meninjau kembali hasil dari kegiatan belajar. Dari beberapa pendapat diatas, diperoleh bahwa pembelajaran merupakan kegiatan belajar yang dilakukan untuk siswa didesain guru agar mencapai hasil belajar yang maksimal. Berdasarkan pengertian dari para ahli tersebut, dapat ditarik garis lurus bahwa tugas guru bukan hanya ada dalam kegiatan belajar mengajar tetapi juga merancang sebuah kegiatan pembelajaran di sekolah. Dengan demikian, kegiatan pembelajaran siswa dan guru yang telah dirancang berdasarkan kurikulum yang telah ditentukan sehingga siswa bisa mencapai hasil belajar yang maksimal sesuai dengan kompetensi yang telah dipersiapkan. Mata pelajaran muatan lokal yaitu Bahasa Madura dalam Pergub JATIM No. 19 tahun 2014 menyatakan bahwa mata pelajaran muatan lokal Bahasa Madura ini diwajib pada Sekolah Dasar di Madura dan lingkungan yang menggunakan masyarakatnya menggunakan Bahasa madura. Materi mata peljaran Bahasa Madura ini menyampaikan sebuah kegiatan pembelajaran Bahasa Madura dengan durasi waktu pelaksanaan selama dua jam pelajaran di sekolah selama kurun waktu satu minggu, dalam proses penelitian berjalan dengan lancer dan memberikan infomasi yang bermanfaat.. 
Pendas : Jurnal IImiah Pendidikan Dasar, ISSN Cetak : 2477-2143 ISSN Online : 2548-6950 Volume VI Nomor 01, Juni 2021

\section{B. Metode Penelitian}

Metode penelitian yang digunakan pendekatan Research and Development atau lebih sering disebut dengan penelitian pengembangan. Penelitian ini nantinya menghasilkan sebuah produk baru berinovatif. Menurut (Sitepu, 2012) R\&D juga mempunyai definisi sebagai metode penelitian secara sengaja, sistematis, memperbaiki, mengembangkan, dengan tujuan atau mengarahkan untuk dirumuskan, menghasilkan, menguji kefektifan sebuah produk, jasa, model, metode/strategi/cara, prosedur tertentu lebih unggul, efisien, produktif, baru, efektif, serta juga bermakna.

Dari definisi di atas, penelitian ini akan mengembangkan sebuah Buku pepak bahasa Madura pada siswa kelas Sekolah Dasar (SD). Menurut (Sugiyono, 2015) memaparkan dalam penelitiannya bahwa R\&D mempunyai sepuluh langkah, yaitu 1) potensi dan sebuah masalah, 2) pengumpulan dari data, 3) rancangan produk, 4) validasi sebuah desain, 5) revisi terhadap desain, 6) ujicoba produk yang telah dihasilkan, (7) revisi dari produk yang telah dihasilkan,

(8) ujicoba pemakaian produk yang telah dihasilkan, (9) merevisi produk, (10) produksi masal dari hasil produksi.

Peneliti melakukan modifikasi langkah menjadi enam langkah. Tahapan ini digunakan untuk menyesuaikan kebutuhan dari penelitian serta tujuan dari penelitian. Berikut enam langkah penelitian yang dilakukan sebagai berikut: 1) menyusun konsep-konsep teori, 2) menganalisis dari kebutuhan, 3) membuat prototipe, 4) pengujian dari para ahli, 5) revisi terhadap produk, dan 6) pengembangan dari prototipe.

Langkah awal yang harus dilakukan untuk mengembangkan prototipe adalah dengan menyusun konsep-konsep teori yang terdapat didalamnya mencakup kegiatan mencari sumber referensi dan hasil penelitian yang relevan dengan penelitian tersebut.

Langkah selanjutnya yaitu merupakan menganalisis sebuah kebutuhan. Dalam langkah kedua ini akan melakukan aktivitas mencari data yang diperlukan untuk menyusun sebuah buku pepak bahasa Madura untuk siswa. Pada langkah ketiga ini adalah dengan pembuatan prototipe sebuah buku pepak berbahasa Madura, yang 
mencakup kegiatan adalah sebagai berikut: a) dikumpulkan serta ditentukannya bab sebagai bahan mengembangkan untuk buku pepak bahasa Madura untuk anak SD, b) mengkaji format dari buku pepak bahasa Madura Siswa Dasar, serta c) disusunnya buku pepak bahasa Madura anak Sekolah Dasar.

Langkah keempat ini adalah menguji hasil dari pengembangan prototipe hasil awal yang di berikan kepada para ahli. Pengembangan buku pepak bahasa Madura yang dihasilkan akan diuji kelayakannya kepada para ahli yang telah dipilih penelti yakni Dosen Ahli, Guru, serta Budayawan Madura.

Langkah berikutnya yakni merevisi prototipe dari buku pepak bahasa Madura yang diperuntukkan anak Sekolah Dasar yang terdiri dari: a) identifikasi serta data yang menghasilkan penilaian dari guru yang bersangkutan, dosen ahli, serta budayawan Madura, b) pengolahan data dari penelitian, dan juga c) ditemukannya kelemahan dari produk penelitian.

Langkah terakhir yang harus dilakukan dalam pembuatan pengembangan ini adalah pengembangan buku pepak bahasa
Madura. Langkah-langkah tersebut pembuatannya bisa dilihat dalam kerangka bagan pada gambar 1 .

Menurut (Arikunto, 2005) Subjek penelitian merupakan suatu benda, hal atau orang tempat dari data sebagai variabel yang melekat, serta yang menjadi permasalahan. sejalan dengan alur penelitian, yakni-

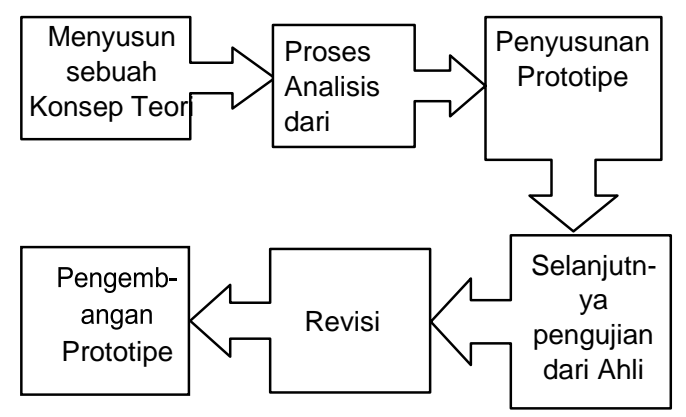

Gambar 1 Langkah-langkah metode (R\&D)

-pengembangan pepak bahasa Madura anak Sekolah Dasar, yang menjadi subjek dipenelitian ini terdiri dari dua tahapan. Pertama sebagi subjek penelitian dalam tahap menganalisis kebutuhan yakni guru. Subjek penelitian kedua adalah tahap menguji kelayakan dari produk yang dihasilkan adalah guru mata pelajaran Bahasa maduar, dosen ahli bahasa, serta budayawan Madura.

Deskripsi keseluruhan dari instrumen yang telah dipergunakan pada penelitian tertera pada kisi-kisi tabel sebagai berikut, yaitu mengenai hal sudah di bahas.. 
Pendas : Jurnal Ilmiah Pendidikan Dasar, ISSN Cetak : 2477-2143 ISSN Online : 2548-6950 Volume VI Nomor 01, Juni 2021

Tabel 1 Instrumen dari Penelitian

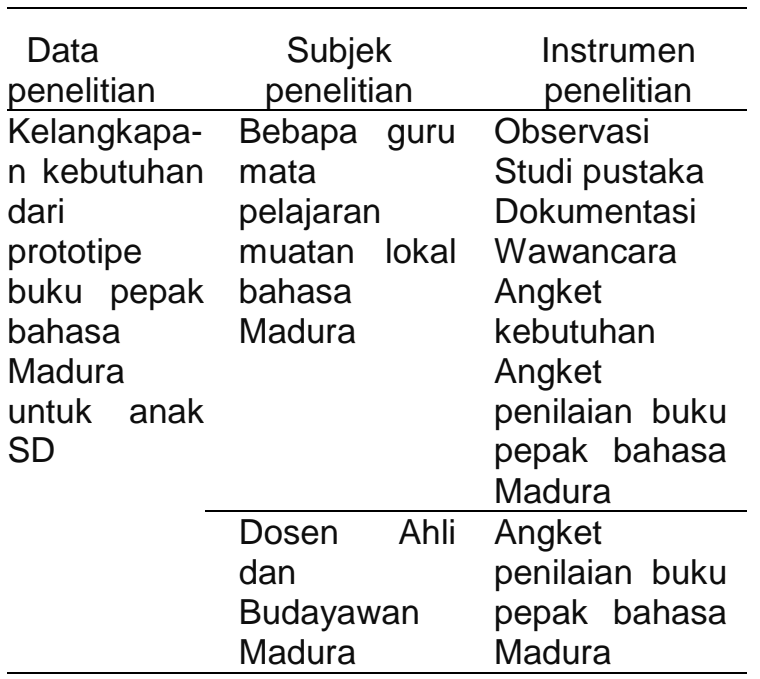

Penyusunan Instrumen diujicoba pada Dosen Ahli Bahasa sebelum nantinya bagikan pada para responden, hal ini bertujuan untuk uji coba yang dilakukan supaya instrumen yang telah tersusun memiliki validitas isi yang baik.

Kebutuhan angket prototipe buku pepak bahasa Madura untuk siswa Sekolah Dasar ini adalah angket kebutuhan dari guru. Pemerolehan data dari angket akan menjadi sebuah bahan pengembangan dari prototipe pepak bahasa Madura pada siswa Sekolah Dasar, serta angket penilaian prototipe buku pepak bahasa Madura.

Pada penelitian ini menggunakan teknik pengumpulan data berupa observasi lapangan, studi pustaka dari berbagai sumber, dokumentasi data, wawancara narasumber, dan menggunakan angket. Data yang telah terkumpul dipergunakan sebagai penganalisis kebutuhan selanjutnya dilakukan perbaikan dari produk dalam proses pembuatan dari prototipe pepak bahasa Madura untuk siswa Sekolah Dasar.

\section{Hasil Penelitian dan Pembahasan}

\section{Studi awal}

Tahap awal studi dari pengembangan buku referensi Pepak Bahasa Madura yang dikembangkan pada kelas atas SD pada kecamatan Bangsalsari Jember, dikumpulannya informasi penelitian yang akan dilakukan yaitu dengan studi pustaka dari berbagai sumber, wawancara narasumber, dan observasi lapangan.

a. Studi Pustaka

Studi pustaka ini, serang peneliti menganalisis tentang literatur yang berhubungan dengan buku referensi mata pelajaran. Hasil pengkajian pustaka ini memperoleh dasar untuk dijadikan sebagai pedoman peneliti dalam pengembangan produk dari buku referensi yang telah dirancang. Berdasarkan pemerolehan kajian terhadap sumber literatur maka dihasilkan dasar yang akan menjadi sebuah pedoman

untuk 
Pendas : Jurnal IImiah Pendidikan Dasar, ISSN Cetak : 2477-2143 ISSN Online : 2548-6950 Volume VI Nomor 01, Juni 2021

mengembangkan buku referensi yang sesuai dengan kebutuhan pada buku referensi di Sekolah Dasar di kecamatan Bangsalsari Jember.

Terdapat juga kajian teori yang dilakukan peneliti yaitu analisis dari silabus, serta buku-buku referensi guru dalam mempelajari bidang kompetensi yang nanti akan dicapai pada proses pembelajaran. Sejalan dengan hasil studi pustaka dilakukan tersebut, memperoleh yakni pada tema terdapat materi yang diajarkan ada kaitannya dengan lingkungan sekitar serta dapat dikembangkan nilai sosial yang ada pada diri seorang siswa sekolah.

b. Hasil dari Observasi

Observasi yang dihasilkan dapat diketahui bahwasannya seorang guru telah melakukan proses belajar mengajar dengan tidak membosankan, dan juga melakukan variasi dalam pembelajaran. Pembejaran muatan lokal bahasa madura di kelas atas tingkat atas sekolah dasar masih belum dilakukan secara maksimal, hanya terdapat seorang guru yang telah memiliki pemahaman dan melakukan proses belajar mengajar mata pelajaran muatan lokal bahasa madura di kelas, sedang guru yang lain belum belum memahami seutuhnya. Tapi, nilai ketuntasan dalam belajar ini masih belum mencapai nilai yang optimal. Dari pemerolehan data nilai-nilai ulangan para siswa diperoleh yakni $50 \%$ dari siswa telah memenuhi KKM, sedangkan $50 \%$ siswa masih belum memenuhi KKM. Oleh karna itu, perlu adanya buku referensi yang bisa menambah pemahaman dalam pembelajaran serta meningkatkan prestasi belajar siswa.

c. Wawancara Kebutuhan Guru

Dari bebarapa narasumber diperoleh hasil wawancara dengan seluruh guru tersebut diperoleh informasi bahwa penggunaan buku referensi pepak bahasa madura belum digunakan secara maksimal. Selama pembelajaran ini biasanya buku yang dipergunakan mata pelajaran muatan lokal Bahasa madura, berupa buku referensi yang tidak ditulis oleh guru terkait mulok Bahasa Madura. Meskipun, telah ada beberapa yang menggunakan buku referensi (yang ditulis oleh guru yang bersangkutan), namun dalam isinya masih terdapat beberapa kekurangan. Dalam menyiapkan pembelaran seharusnya ada beberapa komponen yang disertakan, misalnya Standar Kompetensi, Kompetensi Dasar, 
Pendas : Jurnal Ilmiah Pendidikan Dasar, ISSN Cetak : 2477-2143 ISSN Online : 2548-6950 Volume VI Nomor 01, Juni 2021

indikator belajar, tujuan dalam pembelajaran, materi belajar, prosedur belajar mengajar, evaluasi, dan refleksi. Namun, selama ini tidak semua komponen itu terdapat dalam buku referensi yang telah disusun.

d. Kebutuhan siswa

Berdasarkan hasil wawancara ditemukan bahwa siswa kelas atas masih berkesulitan dengan proses belajar mengajar. Dari beberapa hasil wawancara, diperoleh siswa masih butuh buku referensi yang sesuai dengan proses belajar menjagar siswa dan guru. Hasil dari wawancara yang diperoleh telah mampu menjawab apa saja yang dibutuhkan oleh seorang peneliti untuk mengembangkan sebuah produk pembelajaran buku referensi. Buku referensi yang terancang telah disesuaikan dengan karakteristik lingkungan sekitar di Sekolah.

e. Penyusunan dan

Pengembangan Buku

Perancangan Draft

Menelisik dari kebutuhan guru jadi melanjutkan pembuatan rencana tentang dikembangkannya produk berdasarkan hasil studi pendahuluan yang telah dilakukan peneliti. Rancangan pengembangan ini didasarkan hasil dari studi pendahuluan tersebut. Rancangan produk pengembangan berbentuk buku referensi. Rincian dari susunan perancangan sebagai berikut:
1) Tujuan
pengembangan dirumuskan dengan fokus dikembangkannya buku referensi.

2) Waktu dan keterbatasan penelitian dapat diperkirakan.

Proses pengembangan buku ini didasari dari penguatan pendidikan karakter di lingkungan sekolah berbasis pendidikan multikultural karena daerah jember merupakan daerah yang banyak sekali masyarakat pendatang, masyarakat disana sangat bervariatif. Pendidikan multikultural ini berupa ragam kegiatan yang berhubungan baik sosial serta budaya di lingkungan sekitar daerah.

Setelah menyusun rencana langkah berikutnya yang diambil penyusunan draf pertama buku referensi yang didasari pada tema yang telah ditentukan sebelumnya. Pengembangan produk pada draf pertama harus mengacu pada kajian teori yakni mengacu dalam struktur serta isi buku siswa Sekolah Dasar, yakni berbentuk buku referensi .

1) Pembuatan dari Produk 
Pendas : Jurnal Ilmiah Pendidikan Dasar,

Materi serta bahan yang telah didapat kemudian dirancang dengan software yang bernama Corel Draw, dipadukan dengan Microsoft Word. Program Corel Draw dipergunakan dalam membuat rancangan sampul dari buku serta desain dari beberapa gambar dalam buku. Sedangkan Microsoft Word dipergunakan dalam pembuatan dari isi buku tersebut. Berikut urutan pengembangan buku referensi secara garis besar adalah sebagai berikut:
a. Halaman sampul (cover) terdapat judul tema buku
b. Halaman buku bagian pendahuluan terdapat daftar isi serta kata pengantar dari penulis
c. Bagian awal terdapat materi pendukung proses belajar mengajar

2. Klasifikasi Pengembangan Buku Buku pengembangan referensi didasarkan pada kajian buku-buku yaitu berupa komponen buku yang sangat memperhatikan unsurunsurnya, kelayakan dari isi, bahasanya, penyajian dalam buku, serta grafik dari buku tersebut. Dari segi multikultural diintegrasikan pada kegiatan pembelajaran, materi pembelajarannya, tampilan buku, serta gambar yang ada dalam buku. Kriteria kevalidan buku referensi yang dikembangkan ini agar terpenuhi dilakukan dengan melalui penilaian dari para ahli.

f. Penilaian Produk dari Validator

a. Hasil Validator

Efektifitas untuk mengetahui produk akhir yang telah dibuat dalam penelitian dilakukan dengan teknik tes instrumen dengan pembagian buku referensi yang berbentuk digital dalam mengukur keefektivifan dari produk. Pembagian buku referensi digital bahasa madura yang dilakukan supaya bisa untuk dapat mempertanggungjawabkan dari isi kualitas buku sebagai alat untuk mengukur dan memenuhi prinsip dari validasi yang nanti akan diujicobakan pada siswa sekolah dasar.

1) Hasil Validasi buku referensi

Berdasarkan hasil uji kelayakan dilakukam oleh 3 guru dan 15 siswa, diperoleh skor total dari tiga guru dan slimabelas siswa pada segi bahasa 600 , segi materi diperoleh 624 , serta dari segi media berupa penyajian 640. Jadi Jumlah dari rerata segi bahasa 50 , segi materi 52 , segi media dari segi penyajian 53. Dari beberapa segi aspek masing-masing 
Pendas : Jurnal Ilmiah Pendidikan Dasar, ISSN Cetak : 2477-2143 ISSN Online : 2548-6950 Volume VI Nomor 01, Juni 2021

memperoleh adalah kategori yakni "sangat baik".

\section{b. Revisi I Produk}

Setelah melakukan validasi, draf pertama (I) berikutnya merevisi yang didasarkan pada saran serta masukan yang diperoleh dari validator. Validasi yang dihasilkan pada draf pertama berupa saran-saran yang diberikan oleh validator masing-masing serta merevisi tahap pertama yang didapat dari para ahli, dan juga guru yang terkait. Saran serta hasil dari revisi oleh para ahli serta guru yang telah tertera pada Tabel berikut.

Tabel 2 Penilaian Kelayakan dari buku referensi oleh Guru dan Siswa

\begin{tabular}{|c|c|}
\hline Sebelum revisi & Setelah Revisi \\
\hline \multicolumn{2}{|c|}{ (Kelayakan dari segi Isi) } \\
\hline $\begin{array}{l}\text { Rata jarak, kanan, } \\
\text { atau kiri dan bawah } \\
\text { tidak runtut }\end{array}$ & $\begin{array}{l}\text { Telah diperbaiki } \\
\text { anatara rata jarak } \\
\text { kanan atau kiri, } \\
\text { bawah supaya } \\
\text { menjadi runtut. }\end{array}$ \\
\hline $\begin{array}{l}\text { Belum dibuat kolom } \\
\text { supaya lebih mudah } \\
\text { dipahami }\end{array}$ & Sudah diperbaiki \\
\hline \multicolumn{2}{|c|}{ (Kelayakan dari segi Bahasa) } \\
\hline $\begin{array}{l}\text { Huruf yang tercetak } \\
\text { harus sesuai dengan } \\
\text { SK dirjen Dikdasmen }\end{array}$ & $\begin{array}{l}\text { Telah diperbaiki } \\
\text { huruf yang } \\
\text { tercetak telah } \\
\text { sesuai dengan } \\
\text { SK dirjen } \\
\text { Dikdasmen }\end{array}$ \\
\hline $\begin{array}{l}\text { Penulisan masih } \\
\text { ditemukan kata-kata } \\
\text { yang terdapat salah } \\
\text { ketik }\end{array}$ & $\begin{array}{l}\text { Telah diperbaiki } \\
\text { penulisannya }\end{array}$ \\
\hline $\begin{array}{l}\text { Harus dapat } \\
\text { membedakan vokal } \\
\text { dalam bahasa } \\
\text { Madura dalam segi } \\
\text { penulisan }\end{array}$ & $\begin{array}{l}\text { Telah } \\
\text { memperbaiki } \\
\text { tata penulisan } \\
\text { supaya dapat } \\
\text { membedakan }\end{array}$ \\
\hline & $\begin{array}{l}\text { vokal pada } \\
\text { bahasa Madura }\end{array}$ \\
\hline
\end{tabular}

\begin{tabular}{|c|c|}
\hline Sebelum revisi & Setelah Revisi \\
\hline \multicolumn{2}{|c|}{ (Kelayakan dari segi Isi) } \\
\hline \multicolumn{2}{|c|}{ (Kelayakan kegrafikan dan penyajian) } \\
\hline $\begin{array}{l}\text { Beberapa ukuran } \\
\text { gambar terlalu } \\
\text { Kecil dan kurang } \\
\text { menarik }\end{array}$ & $\begin{array}{l}\text { Mengubah ukuran } \\
\text { gambar dan } \\
\text { mengganti dengan } \\
\text { yang lebih menarik }\end{array}$ \\
\hline $\begin{array}{l}\text { Warna latar } \\
\text { belakang kurang } \\
\text { kontras }\end{array}$ & $\begin{array}{l}\text { Memperbaiki warna } \\
\text { latar belakang }\end{array}$ \\
\hline $\begin{array}{l}\text { Nomor pada } \\
\text { halaman masih } \\
\text { terdapat } \\
\text { kesalahan }\end{array}$ & $\begin{array}{l}\text { Telah memperbaiki } \\
\text { penomoran halaman }\end{array}$ \\
\hline \multicolumn{2}{|c|}{ Guru atau Reviewer } \\
\hline $\begin{array}{l}\text { Terdapat gambar } \\
\text { yang harus } \\
\text { diganti denagn } \\
\text { yang sesuai } \\
\text { konteks materi } \\
\text { dalam } \\
\text { pembahasan }\end{array}$ & $\begin{array}{l}\text { Sudah diganti } \\
\text { gambar sesuai yang } \\
\text { sesuai konteks pada } \\
\text { materi yang dibahas }\end{array}$ \\
\hline $\begin{array}{l}\text { Belum terdapat } \\
\text { biodata dari penulis }\end{array}$ & $\begin{array}{l}\text { Telah menambah } \\
\text { biodata penulis pada } \\
\text { buku }\end{array}$ \\
\hline
\end{tabular}

Hasil Uji Produk

Uji coba dibatasi untuk mendapat data yang berhubungan dengan buku referensi yang telah dikembangkan. Uji coba pertama pada subjek uji coba yakni pada siswa Sekolah berjumlah 15 siswa dari 3 sekolah masing-masing perwakilan lima siswa dan satu guru sebagi pemandu persekolah. Tujuan dari pelaksanaan uji coba pertama agar dapat memperoleh informasi sebagai bahan dalam memperbaiki pengembangan dari produk buku referensi yang digunakan pada langkah berikutnya. Perolehan hasil pada uji coba pertama berbentuk 
analisis dari hasil wawancara guru dan siswa, data-data yang dihasilkan tentang respon dari guru dan respon siswa SD pada buku referensi. Analisis data uji coba sebagai berikut:

1. Respon Guru dengan Buku Referensi

Hasil dari respon guru diperoleh melalui cara diberikannya buku pada tiga orang guru. Dai beberpa hasil wawancara buku referensi yang diperoleh guru memaparkan bahwa materi yang telah diajarkan telah sesuai dengan proses belajar mengajar di sekolah. Telah diperoleh juga bahwa buku referensi yang dipergunakan telah mencakup materi muatan lokal bahasa madura yang ada dilingkungan sekitar siswa, akan tetapi dalam pengintegrasian materi muatan lokal bahasa madura guru memberikan saran supaya materi ilmu sosial budaya dapat tersajikan dasarnya saja, karena buku referensi akan digunakan untuk siswa sekolah dasar.

Dari beberapa hasil wawancara, secara keseluruhan buku referensi yang dikembangkan dari aspek materi, bahasa serta media telah baik. Hanya terdapat beberapa yang harus menjadi unsur masukan peneliti yang perlu dilakukannya revisi, supaya dapat dipergunakan pada tahapan berikutnya.

\section{Respon Siswa}

Data-data respon dari siswa diperoleh melalui cara dengan membagikan buku pada 15 siswa. Peneliti melakukan wawancara terhadap 15 siswa di Sekolah. Dari beberapa hasil wawancara buku referensi yang telah dikembangkan siswa menyatakan hasil bahwa buku referensi ini telah memudahkan para siswa SD dalam proses belajar dengan buku yang menarik untuk dibaca. Penyajian gambar dalam buku lebih terlihat jelas, serta telah sesuai pada materi bahasan serta dapat mudah untuk dibaca siswa. Petikan siswa tentang buku referensi sebagai berikut: Siswa semakin senang belajar dengan menggunkan buku yang telah dikembangkan ketimbang dengan buku dari telah disediakan oleh guru yang bersangkutan.

Berikut cuplikan wawancara siswa: diperoleh hasil wawancara, dari keseluruhan buku referensi ini dikembangkan pada aspek materi yang lebih mudah untuk dipahami, dari aspek bahasa penulisan sudah cukup jelas serta dapat terbaca dengan baik, dari aspek media diteliti dari halaman depannya warna lebih 
Pendas : Jurnal Ilmiah Pendidikan Dasar, ISSN Cetak : 2477-2143 ISSN Online : 2548-6950 Volume VI Nomor 01, Juni 2021

terliahat cerah, sehingga lebih menarik para siswa dalam belajar, dari aspek gambar ilustrasinya yang terdapat dalam buku ini gambar lebih terlihat jelas dari sebelumnya.

\section{Kesimpulan}

Hasil dari studi pustaka peneliti menganalisis juga silabus, serta buku referensi guru yang dipelajari berupa kompetensi yang dicapai. Dari beberapa hasil studi pustaka yang dilakukan, memperoleh bahwa tematema yang terdapat dalam materi ajar yang terkait dengan lingkungan sekitar serta pengembangan dari nilai sosial yang ada pada siswa itu sendiri.

Observasi hasil yang diperoleh yakni guru yang bersangkutan telah melakukan proses belajar mengajar dengan menyenangkan, dan juga lebih bervariasi. Pembejaran muatan lokal bahasa madura di kelas atas tingkat adtas sekolah dasar belum dilaksanakan secara optimal, hanya 1 guru yang memahami dan melaksanakan pembejaran muatan lokal bahasa madura di kelas, sedangkan guru lainnya belum memahami sepenuhnya.

Hasil wawancara kebutuhan guru dengan seluruh guru tersebut diperoleh informasi bahwa penggunaan buru referensi pepak bahasa madura dinilai masih belum cukup maksimal. Proses pembelajaran yang dilakukan sejauh ini menggunakan buku acuan mata pelajaran muatan lokal Bahasa Madura dari guru tersebut namun bukan hasil karya guru tersebut yang berupa buku teks. Sedangkan dilihat dari kebutuhan siswa berdasarkan pemerolehan hasil dari wawancara diperoleh bahwasannya siswa pada kelas atas masih kesulitan untuk proses pembelajaran. Berdasarkan dari hasil wawancara, ditemukan siswa memelukan buku referensi yang sesuai dengan pelajaran muatan lokal bahasa madura pada siswa sekolah dasar. Buku referensi yang telah didesain harus disesuaikan dengan karakteristik diharapkan dari pihak di Sekolah.

Penyusunan Draft yang dilihat kebutuhannya disampaikan guru bahwa dilakukan proses lanjutan dengan membuat rancangan buku pengembangan produk yang berdasarkan dari hasil studi pendahuluan yang diperoleh. Rancangan pengembangan dari produk buku ini berdasarkan dari hasil studi pendahuluan penelitian. Rancangan pengemabangan produk 
Pendas : Jurnal Ilmiah Pendidikan Dasar, ISSN Cetak : 2477-2143 ISSN Online : 2548-6950 Volume VI Nomor 01, Juni 2021

buku ini berupa buku referensi Pepak Bahasa madura.

Efektifitas produk final mengetahui dengan pemerolehan hasil penelitian yang digunakan dengan menggunakan teknik tes yang berisikan instrumen berupa pemberian buku referensi yang berbentuk digital agar dapat mengukur efektivitas dari produk. Pembagian buku dilakukan guna untuk bisa atau dapat meningkkatkan dan mempertanggungjawabkannya.

\section{DAFTAR PUSTAKA}

Ardiyani, D. R. (2013). Peningkatan Keterampilan Membaca Aksara Jawa Melalui Model Quantum Learning dengan Media Kartu Kata Siswa Kelas III A SDN Petompon 02 Semarang. Universitas Negeri Semarang.

Arikunto, S. (2005). Manajemen Penelitian. Jakarta: PT Rineka Cipta.

Dimyati; Mudjiono. (2002). Belajar dan Pembelajaran. Jakarta: Rineka Cipta.

Fifana, R. (2012). Pengembangan Panduan Membuat Majalah Sekolah untuk Siswa SMP. Fakultas Bahasa dan Seni, Universitas Negeri Semarang, Semarang.

Halim, A. (1976). Politik Bahasa Nasional 1 dan 2. Jakarta: Penerbit Aneka IImu.
Lestari, T. (2011). Pengembangan Bahan Ajar Cerita Berbasis Konservasi Budaya Bagi Siswa SD Kelas Tinggi. Jurusan BaFakultas Bahasa dan Seni, Universitas Negeri Semarang.

Nunung Nurjanah, R. D. L. (2018). Pengaruh Penggunaan Buku Ajar Pendidikan Pancasila dan Kewarganegaraan Berperspektif Gender Terhadap Peningkatan Pengetahuan Kesetaraan Gender Pada Siswa Kelas Lima SDN Kedokan Bunder 1 Kecamatan Kedokan Bunder Kabupaten Indramayu. Pendas: Jurnal IImiah Pendidikan Dasar, III(2), 133-145. Retrieved from https://journal.unpas.ac.id/index.ph $\mathrm{p} /$ pendas/article/view/1359

Prastowo, A. (2011). Panduan Kreatif Membuat Bahan Ajar Inovatif. Yogyakarta: Diva Press.

Sitepu, B. . (2012). Penulisan buku teks pelajaran. Bandung: PT Remaja rosdakarya.

Sugiyono. (2015). Penelitian \& Pengembangan (Research and Development/R\&D). Bandung: Alfabeta.

Undang-Undang Dasar Negara Republik Indonesia 1945. (n.d.). Surabaya: $\mathrm{CH}$. Cahaya Agency.

Wicaksono Alam, A., \& Fikri Bariska, H. (2018). Pengembangan Buku Ajar Bahasa Indonesia Berbasis Pendidikan Karakter Dengan Model Assure Pada Siswa Sekolah Dasar. Pendas: Jurnal IImiah Pendidikan Dasar, III(2), $1-10$. https://doi.org/10.23969/jp.v3i2.123 5 